\title{
Metric Power and the Academic Self: Neoliberalism, Knowledge and Resistance in the British University
}

\author{
Zeena Feldman* and Marisol Sandoval** \\ *King's College London, London, UK, zeena.feldman@kcl.ac.uk \\ ${ }^{* *}$ City, University of London, London, UK, marisol.sandoval.1@city.ac.uk
}

\begin{abstract}
This article discusses the experience of being an academic in the UK in the contemporary climate of neoliberal capitalism and 'metric power' (Beer 2016). Drawing on existing literature and our own practice, the first portion of the paper explores the relationship between neoliberalism, metrics and knowledge. We then examine how neoliberal mantras and instruments impact the university's structures and processes, and reflect on consequences for the academic self. We take as a starting point the context of increasing workloads and the pressure on academics to excel in multiple roles, from 'world-leading' researchers to 'excellent' teachers and 'service providers' to professional administrators performing recruitment and (self)marketing tasks. Neoliberal academia, we suggest, promotes a meritocratic ideology of individual achievement that frames success and failure as purely personal 'achievements', which encourages a competitive ethos and chronic self-criticism. This article insists that these problems need to be understood in the context of neoliberal policy-making and the corporatisation of knowledge, including funding cuts and grant imperatives, the low status of teaching, the cynical instrumentation of university league tables, and increased institutional reliance on precarious academic labour. The article goes on to focus on responses that resist, challenge or, in some cases, compound, the problems identified in part one. Responses by dissatisfied academics range in style and approach - some decide against an academic career; others adopt a strategy of individual withdrawal within the system by trying to create and protect spaces of independence - for example, by refusing to engage beyond officially required minimums. This article argues that opportunities for positive systemic change can be found in collective efforts to oppose the status quo and to create alternatives for how academic labour is organised. Therein, solidarity can act as an instrument of opposition to the individualisation of the neoliberal academic self.
\end{abstract}

Keywords: Academic Labour, UK Academia, Metrics, Metric Culture, Higher Education Policy, Neoliberalism, Resistance, Co-operative University, Trade Unions

What does it mean to be an academic in the UK today? While the modern university has always been enmeshed in capitalist structures (see Allmer, this issue), higher education in the UK has, since the late 1970s, been thoroughly recalibrated by the 'logic' of the market (De Angelis and Harvie 2009, 6). In that time, government and university policymakers have worked to steadily align the university's legitimacy with the skills needs of industry, the competitive ethos of business and the organisational principles of managerialism. Much has been written analysing this 'neoliberal turn' in higher education, offering either systemic critiques of the modern university (e.g. De Angelis and Harvie 2009; Peters and Bulut 2011; Bulut 2011; Toscano 2011; DyerWitheford 2011) or focusing on the experiences of the individual beleaguered academic (Gornall and Salisbury 2012; Gill 2016; Ryan 2012). Yet both scales are, we believe, important to understand the state of contemporary academia. Thus, we hope to contribute to the broader project of locating the dialogue between the university, 
the academic and neoliberalism by making cogent the links between macro and micro in contemporary higher education.

To that end, this article argues that one of the factors connecting the systemic and individual conditions of academia today is the operative hegemony of metric culture (Ajana 2017; Lupton 2016; Moore and Robinson 2015) - what David Beer (2016) calls 'metric power'. Beer's analysis compellingly demonstrates that "metrics are now an embedded, multi-scalar, and active component of our everyday lives - they are central to how those lives are ordered, governed, crafted, and defined" (Beer 2016, 4). To be clear, this is not to say that the existence and use of metrics is a new phenomenon or unique to the digital age; measurement has long been a staple in, for instance, population control, commercial production and labour management efforts (e.g. Braverman 1998; Noble 1997; Foucault 2007). But what is novel, as Beer suggests, is the extent to which "systems of measurement have escalated and intensified over recent years, especially with the rise of new data assemblages and their integration into the very fabric of our lives" (Beer 2016, 4). In this article, we aim to examine how metric power - as a derivative structure of neoliberal capitalism - operates in the British university, and how it acts as the conceptual sinew that binds the macro and micro scales of academic practice.

To begin, and as context, we examine how neoliberal capitalism has impacted upon the societal reputation of knowledge and the public role of the university. From there, we offer a systemic analysis of the British university as a structure of neoliberal capitalist values and mechanisms. Indeed, as Gigi Roggero (2011) and Rosalind Gill (2014) show, "the University has emerged as a cypher or barometer of broader transformations within the economy, and thus a privileged space for 'reading' the contours of contemporary capitalism" (Gill 2014, 17-18). The university thus functions as a productive metaphor for the (mis)workings and (il)logics of a particular economic dogma. As such, we home in on how this economic ideology translates into specific metrics of performance, whether departmentally, institutionally, nationally or internationally.

Following our institutional analysis, the article shifts focus to the ways in which metric power affects the individual academic or 'service provider', in market parlance. We find that these experiences are routinely shaped by the imperative for 'compulsory individuality' (Cronin 2000, in Gill 2016), whereby “individuals are now increasingly required to tell the story of their lives as if they were the outcome of deliberative planning and choice" (Gill 2016, 42). These practices of 'intentional autobiography' consolidated and coherent narratives of the self-coincide with the processes of individualisation (Bauman 2001; Beck and Beck-Gernsheim 2002) by which the individual is held ultimately responsible for the outcome of his/her life. Success as an academic is thus converted into a purely personal accomplishment (or failure) disconnected from the wider social, political and economic contexts that circumscribe knowledge, action and possibility. In focusing on this individualisation (Skelton 2005), we identify some of the choices academics face and their emotional consequences.

After taking account of systemic and individual expressions of metric power in the British university, we focus on strategies of response and resistance. As academics and as workers, we believe firmly in the power of critique. But we also believe that an essential function of critique is its ability to inspire change. To that end, we conclude with thoughts on how we might reimagine the modern university. 


\section{Why Metrics and Why Now?}

As an ideology, neoliberal capitalism reveres competition, promotes social Darwinism and valorises profit (Wigger and Buch-Hansen 2013). It decries regulation and discourages solidarity outside short-term instrumentalism (Giroux 2011). Neoliberal capitalism has been making inroads in British higher education for decades, and as a conceptual framework it substantially informs the context within which the British university must now be thought.

Contributing to this context is a more recent development: widespread rhetorical (and mediatised) disdain for experts and expertise (Nichols 2017). With the rise of global populisms (for a discussion of the Turkish case see, for example: Bakırezer, Demirer and Yeşilyurt in this issue) we see sustained, public attacks on knowledge so extreme that being labelled an intellectual can now be considered pejorative. This sentiment was captured in a recent New Yorker illustration of a man standing in the aisle of a plane insisting, "These smug pilots have lost touch with regular passengers like us. Who thinks I should fly the plane?" (McPhail 2017). In a socio-political climate so hostile to the exercise of knowledge and reason, is it any wonder that figures like the Donald Trump and Nigel Farage are lauded? Or that 'expert' no longer suggests information authority and qualifications but instead signals disconnect from, and scorn for, the masses?

Such discursive attacks on knowledge and expertise sit neatly alongside neoliberal capitalism's reverence for profit-oriented individualism. While knowledge is decried, the tenets of economic competition are encouraged and reproduced. This situation bodes poorly for universities - especially publicly-funded universities - and the academics working in them. This is largely because cultural disregard for knowledge means that universities and academic staff are now required to defend their existence through an alternate language: one of cost-benefit accounting. In other words, knowledge for knowledge's sake is no longer sufficient justification for why we need universities.

With the university effectively forced to articulate itself through the lexicon of neoliberal capitalism, education is recast as a service and educators as service providers. Universities and academics have been reconstituted as extensions of the market (and not only in the UK, e.g. Roggero 2011; Thornton 2013). From this perspective, educating in support of curiosity and criticality is deemed anachronistic, elitist and impractical. With the university thus reconfigured as a business, this narrows both the legitimacy and availability of spaces for thought not aimed at quantifiable forms of understanding (e.g. innovation and commercialisation, grant capture, graduation rates and so on). Ultimately, as Wendy Brown $(2015,176)$ argues, when "education [is seen] as primarily valuable to human capital development, where human capital is what the individual, the business world, and the state seek to enhance in order to maximize competitiveness", the victim is democracy itself. After all, when knowledge is no longer considered a public good or a universal need, then what use is an informed citizenry?

This shift toward knowledge as a private (and thus individual) good is captured by two converging trends: the previously discussed demonisation of expertise on the one hand, and the celebration of the entrepreneur-cum-celebrity on the other (e.g. Steve Jobs, Mark Zuckerberg). This paradox demonstrates that "neoliberalism [...] is best understood not simply as economic policy, but as a governing rationality that disseminates market values and metrics to every sphere of life and construes the human itself exclusively as homo oeconomicus" (Brown 2015, 175). It is precisely in the circulation of this 'governing rationality' that metrics prove so powerful for under- 
standing how higher education is currently organised. Below, we locate and unpack expressions of this power.

\section{Making the University: Institutional Neoliberalism and Metric Power}

Metric power facilitates "focus on the relations between measurement, circulation, and possibility" (Beer 2016, 8). It is a framework that allows insight into the mechanisms and uses of quantification, and one that "contribute[s] towards expanding our understanding of the role of metrics in the performance of contemporary society" (lbid.). Within the university, the role of metrics is extensive and wide-ranging. Indeed, a 2015 report by the Higher Education Funding Council for England (HEFCE) reflected on the 'metric tide' that has washed over higher education in Britain (Wilsdon et al. 2015). The report hints that this dominance of metrics is, in large part, a consequence of how the university is currently conceived by government: namely, as an economic entity which must demonstrate 'value for money' and represent itself through the discourses of competitiveness, efficiency and accountability. From this position, knowledge is transformed into a product and commodity no longer isolated from the marketplace or its rationalisation processes. In other words, government sees higher education as an industry like any other. This is consistent with William Davies's $(2014,38$, in Beer 2016, 134) observation that "reconfiguring institutions to resemble markets is a hallmark of neoliberal government". The provision of knowledge, it would seem, no longer deserves protection from market forces.

This view is confirmed by examination of HEFCE's own governance structures. The agency that is "responsible for distributing public funds for higher education in England"1 and for quality assessment reviews ${ }^{2}$ was, until mid-2016, sponsored by the Department for Business, Innovation \& Skills (now the Department for Business, Energy and Industrial Strategy). ${ }^{3}$ Higher education, in other words, is conceived by policymakers as just one industry among a portfolio of others. Given this overt commercial framing, the prominence of metrics in the university should come as no surprise. To that end, the previously mentioned HEFCE report links the metric tide in academia to:

growing pressures for [...] evaluation of public spending on higher education and research; demands by policymakers for more strategic intelligence on research quality and impact; [...] competition within and between institutions for prestige, students, staff and resources; and increases in the availability of real-time 'big data' on research uptake, and the capacity of tools for analysing them (Wilsdon et al. 2015, viii).

\footnotetext{
${ }^{1}$ HEFCE (2017), TEF National contextual statement for England. Available at: http://www.hefce.ac.uk/media/HEFCE,2014/Content/Learning,and,teaching/TEF/Guidance/ England-TEF-statement.pdf, accessed May 22, 2017.

2 http://www.hefce.ac.uk/reg/assuring/HEFCEs, statutory,duty, accessed 22 May 2017.

${ }_{3}^{3}$ HEFCE, http://www.hefce.ac.uk/about/unicoll/government, and Department of Business, Innovation \& Skills homepage, https://www.gov.uk/government/organisations/departmentfor-business-innovation-skills, accessed May 22, 2017. In July 2016, HEFCE's sponsor department became the Department for Education, but it continues to work with the Department for Business, Energy and Industrial Strategy.
} 
These pressures reflect the extent to which metrics now dominate the university, while actively contributing to the audit culture that saturates British academia (Gill 2014; Shore 2008; Power 1994). Audit culture takes myriad institutional forms, of which the Teaching Excellence Framework (TEF), the Research Excellent Framework (REF) and various League Tables are perhaps the most visible. As such, we focus on these below.

The Teaching Excellence Framework was announced in a May 2016 Government White Paper, Success as a Knowledge Economy: Teaching Excellence, Social Mobility and Student Choice. The TEF was pitched as a sector-wide accountability exercise aimed at recognising, quantifying and promoting high-quality university teaching. Here, top TEF performers would be rewarded with the power to increase student fees. In "incentivising excellent teaching and giving all students better information on where the best provision is found" (Department for Business, Innovation \& Skills 2016, 9-10), the exercise will also necessarily identify underperforming teaching units. The Minister of State for Universities and Science, Jo Johnson, announced in his foreword to the White Paper that "through the TEF [...] we will ensure there are clear incentives for higher education institutions to deliver value to students and taxpayers" (Ibid.). This policy aim succinctly encapsulates the neoliberal capitalist project, where what is valuable is that which is measurable, cost-effective, incomegenerating and conducive to consumer choice. In addition, as the authors of the Alternative White Paper for Higher Education $(2016,28)$ argue, the metrics used for the TEF - for example, student satisfaction statistics - risk undermining teaching quality instead of improving it.

The White Paper's title links knowledge to the economy, not to learning. This further demonstrates that UK policymakers appreciate knowledge cultivation primarily through the narrow lens of economic development. According to the government, "teaching excellence matters, not only for students and taxpayers, but also for those who care about social mobility, since we will not truly begin to reduce inequality unless more students fulfil their aspirations and progress on into their chosen careers" (Department for Business, Innovation \& Skills 2016, 13). This justification for the TEF hinges exclusively on metrics of economic success: value-for-taxpayer-money, 'social' mobility and employment rates. The task of educating, in other words, is a means to a (purely fiscal) end where knowledge acquisition is a modality for economic reproduction and advancement.

As much as we would like to take seriously the TEF's stated aim of reducing inequality, the attendant logic is flimsy, at best. The TEF is a competitive exercise and the data it generates will be used to construct a league table. The process of ranking universities - in this case, by alleged teaching quality - results in performance indicators that range from high to low. The very task of ranking institutions necessarily foregrounds inequalities: some universities will do well, others will do less well. It is difficult to understand, then, how a competitive exercise that quantifies relative excellence (and failure) will be able to reduce inequality when the very point of the exercise is to highlight performance differences between institutions. In other words, how can measuring inequality and promoting competition lead to greater equality? It is useful to consider this question vis-à-vis William Davies's argument that "a society that celebrates and encourages 'competitiveness' as an ethos, be it in sport, business, politics or education, cannot then be surprised if outcomes are then highly unequal" (Davies 2014, 41; see also Beer 2016, 133-134). Inequality here is a key product of neoliberal systems of production, and it is a product with utility. Davies notes that "critical denunciations of inequality as 'illegitimate' may miss the ways in 
which inequality is 'legitimate' because it is publicly and enthusiastically legitimated" (2014, 41, emphasis original). As such, we suggest that the TEF ought to be regarded as a public, state-sanctioned legitimation, if not acceleration, of inequality.

Moreover, we can consider the Research Excellence Framework (REF) - the much-maligned, sector-wide audit of university research - in the same light. Rising from the ashes of the Research Assessment Exercise (RAE), the REF aims to measure and rank universities by the quality of their research activities (see Jump 2013). The RAE was initially conceived in the 1980 s as an exercise by which to determine distribution of central government research funding in a climate of decreased state investment in higher education (Evans 2004). The universities that performed best would effectively get the most research funding.

Today's REF performs a similar function. Through a variety of metrics and data sources (see Stelmach and Von Wolff 2011, 71), the REF foregrounds and reifies inequalities within UK higher education. The REF relies on expert sub-panels to quantify research quality by subject area (Ibid.). These panels are a means of harmonising disciplines across universities; they facilitate systemic standardisation of, say, sociology or philosophy, that allows for easy comparison between different academic departments offering the same degree. The REF also evaluates research quality at the institutional level, measuring factors like impact and research environment. ${ }^{4}$ Coordinated every five years (or so) by HEFCE, the REF produces a powerful league table by which British universities' fiscal and reputational health is (re)produced.

The resulting hierarchy informs other indices of academic competitiveness because it contributes to other university league tables - for instance, the Complete University Guide, The Times and Sunday Times University Guide and the QS World University Rankings. League tables, Thornton $(2013,131)$ observes, are a "manifestation of the way competition policy is retained at the forefront of the institutional academic agenda. They entail universities competing with one another for rankings at the national and international level, based on a range of reputational factors". Through league tables we see the vagaries of reputation named and quantified, and wrought through the hegemony of metric power.

In the higher education industry, universities are concerned with market share visà-vis their competitors. After all, HE is big business and for the UK, a big export product. The lobbying organisation Universities UK, for example, reported that in 2014-2015, "on- and off-campus spending by international students and their visitors generated $£ 25.8$ billion in gross output". ${ }^{5}$ Such large financial stakes make academic measurement all the more appealing. The REF, TEF and university league tables can thus be understood as industry-specific performance indicators. They are the frameworks by which university quality - understood in the neoliberal context through descriptors like 'entrepreneurial' and 'competitive' - is quantified. Moreover, they establish concrete metrics that double as benchmarks against which future performance can be measured, and rewarded (or punished) accordingly. Indeed, as HEFCE's metric tide report indicates, "across the higher education sector, quantitative data is now used far more widely as a management aid, reflecting developments in the private sector over recent decades" (Wilsdon et al. 2015, 179). Metrics, then, are

\footnotetext{
${ }^{4}$ http://www.ref.ac.uk/panels/assessmentcriteriaandleveldefinitions, accessed May 23, 2017.

5 Universities UK, 2017, http://www.universitiesuk.ac.uk/policy-andanalysis/reports/Pages/briefing-economic-impact-of-international-students.aspx, accessed
} May 23, 2017. 
not about measurement for measurement's sake. Rather, they are a means of disciplining universities and academics by laying bare what is valued (and not) in the $\mathrm{HE}$ marketplace. In the following section, we focus in greater depth on the experiences of individual academics to consider how metric power works at the micro level.

\section{Making the Academic: Measurements of Self}

Having explored institutional expressions of metric power in the university, we now wish to consider how these systems impact individual academics. How does today's metric culture and the neoliberal conception of knowledge production affect the academic practitioner?

To answer this question, it is essential to return to the currently dominant societal understanding of knowledge as industry. As Margaret Thornton $(2013,131)$ notes, "instead of being regarded as a public good, higher education has become a commodity. Within the new 'industry', students have become customers who purchase a product from service providers". This move away from knowledge as a public good has consequences for the subjectivities available to academic staff. One finds that these 'new' subjectivities have little in common with the ideals of passionate vocation so often invoked in the popular imaginary (Gill 2016). Indeed, Thornton suggests that today's ideal academic is the "technopreneur" (Thornton 2013, 130) who is "expected to be economically productive [...] [This] new culture exerts pressure on academics to create knowledge - not for its own sake [...] but for its use value in the market" (lbid., 131). This ideal is encouraged through imperatives for knowledge transfer or third mission activity (e.g. Gaze and Stevens 2011).

With the educator-researcher recast as a service provider and an economically productive unit, a new lexicon narrates the academic self. That lexicon is shaped by the values of neoliberal capitalism. Herein, "'good investment' is the way departments speak of new hires, and 'entrepreneurial' has become a favored term for describing exceptionally promising young researchers" (Brown 2015, 195). Brown goes on to argue that this mechanistic commercialisation of knowledge production creates two tiers of scholarship. The first is research that is institutionally recognised and therefore good for one's career. The second is research that delinks knowledge from corporate-ladder calculation and is aligned instead with thinking as an ethical doing. In other words, the professionalisation of higher education - with incentives around grant capture and knowledge transfer, among others - "widen[s] the breach between research valued and rewarded by the disciplines and research that is profound, useful, exciting, or relevant to making better worlds or better citizens" (Ibid., 196; see also: Gaze and Stevens 2011). It would thus seem that inside the neoliberal university, economics trumps civic responsibility.

Unpacking this prioritisation reveals an interesting perversion of how the academic - and her societal function - is understood. Consider the reputational and structural position of teaching activity in the university. In the UK (though not only), university budgets rely heavily on tuition fees. Data collated by the Higher Education Statistics Agency (HESA 2017, Table 16) shows that in 2015-2016, UK universities received 48 per cent of their income from tuition fees and education contracts. By contrast, those same universities received only 17 per cent of their total income from research grants and contracts (Ibid., Table 16). ${ }^{6}$ Structurally, these figures suggest that teach-

${ }^{6}$ These figures represent averages across the UK higher education sector; the numbers can vary widely between individual universities. These figures also do not take account of other 
ing represents a far more vital (i.e. lucrative) activity than research. In neoliberal accounting parlance, it 'outperforms' research as an income stream by nearly three to one. As such, one would be forgiven for taking this thinking to its logical (capitalist) conclusion: if teaching earns so much more money than research, the ideal academic is one who does more teaching and less research. And yet...

This is where illogic comes into play. For students and staff alike, the desirability of a university is driven in large part by its reputation - its cultural capital. And that derives heavily from the research profile of an institution, measured by the REF, and variously by grant capture, knowledge transfer, research outputs and perhaps soon, citation counts (Gruber 2014, 166). So while teaching earns universities money, it does not garner prestige. Yet prestige is what enables universities to attract 'the best' people. Thus, academics are incentivised to focus on our research, because that is what benefits individual careers and institutional reputations. It is through our research activities that we distinguish ourselves in a highly competitive marketplace. Unfortunately, such rational prioritisation drives academics away from the task of educating students (never mind pastoral care). As Brown $(2015,196)$ laments:

neoliberalization has dramatically depressed the status of undergraduate teaching within the academic profession as a whole and at public research universities, in particular. Since research is all that enhances scholarly value, all savvy young faculty learn to allocate most of their human capital portfolio to it. Teaching steals precious time from research, and too much care for undergraduate teaching also stigmatizes academics.

The TEF was introduced, in part, to address the disincentive to teach. Yet because the TEF is simply another set of metrics and rankings - in other words, because it employs the same instrumentalist logic that is under critique here - we expect the exercise will do precious little to improve teaching's reputation or salvage it from the neoliberal values of individualism, efficiency and profit. Instead, it will likely contribute to the academic's (already heavy) load of performance pressures.

Metric power, as an outgrowth of neoliberal ideology, holds sway over academic livelihoods in other ways. Perhaps most pernicious are the pressures and attendant metrics of publication. In the UK, the familiar 'publish or perish' motto has been rewritten. It is no longer enough just to publish; one must publish in the 'right' formats, with the 'right' presses, in the 'right' journals and in the 'right' timeframes. While it is not official guidance, book chapters are undesirable REF submissions. Likewise, for monographs, university presses are preferable to commercial publishers. For articles, one should target journals with high impact ratings. And above all, one must produce

important income sources. Specifically, they do not include funding body grants, which represent a further 17 per cent of university income (HESA 2017, Table 16). These grants consist of research and teaching grants, but we do not include these details because the precise split between research and teaching grants varies by institution. Another 17 per cent of university income in 2015-2016 came from what the financial report terms 'other income'. This consists, in part, of 'other services rendered' to 'BEIS Research Councils, UK central government/local authorities, health and hospital authorities, [and] EU government bodies'; income from 'residences and catering operations'; grants from local authorities; and 'income from intellectual property rights' (HESA 2017, Table 16). 
a requisite number of publications per REF cycle ${ }^{7}$ that will be dubbed 3-star ('internationally excellent') or 4-star ('world-leading') by subject area sub-panels.

Quality in research matters. But so does quantity. As shown above, the REF consolidates both imperatives by expecting each academic to submit an average of 2.5 publications of 3-, or ideally, 4-star quality in the upcoming assessment cycle. This pushes for an acceleration of output, where one is compelled to publish as much as possible in order to meet that REF target. The most efficient way to achieve this is by getting as many publications out of a single research project as one can, regardless of whether one has anything new to say. At a recent conference, a speaker wryly described this strategy as 'slicing the salami really thin'. The successful academic, in other words, is one who is concerned with maximum value extraction and resource efficiency. This model might be applicable for management of limited natural resources like petroleum or silicon, but for us, its application to knowledge production is deeply troubling. Such quantitative reductionism is also seen in the growing emphasis on citation counts (Hicks et al. 2015). As Thomas Gruber $(2014,166)$ notes, "accumulating as many citations as possible [is an] important 'means' for academics to improve their own and their institution's reputation and to advance their career ('ends')".

Metric power affects academic priorities in other ways. Among these is the imperative for grant capture. In a neoliberal economy with ever-decreasing state support for higher education, it is increasingly important that individual academics acquire external grants to support their research. Such grants contribute to universities' balance sheets but their import far transcends profit-loss accounting. First and foremost, bigenough grants enable academics to be 'bought out' of their teaching obligations. Because, and as previously discussed, teaching is a reputationally undesirable activity, it is in academics' interest to avoid it. Grants provide a key mechanism by which to do so.

Where buyout occurs, universities generally use a portion of the grant to hire temporary staff to cover the permanent employee's teaching load. This mechanisation of grant income fuels an ongoing labour crisis in British (but not only) universities. At its simplest, the crisis can be understood as an academic class system. The bottom of the hierarchy is populated by those on short-term, usually part-time contracts. These colleagues are paid hourly for teaching and marking, and receive no institutional research support. Meanwhile, at the top of the hierarchy are academics on permanent full-time contracts that can go after research grants, with access to university resources, and then use grant income to get teaching buyout and secure more time to produce more research outputs (i.e. what advances careers).

This structural arrangement can result in a toxic emotional cocktail at both ends of the academic class system. Precarious and permanent staff alike feel severe pressure to perform in industry-approved, quantifiable ways and this routinely leads to working far more hours than contractually obligated (e.g. Gill 2016, 45-46). Evenings and weekends become extensions of the workday, providing much-needed opportunities to catch up or, at least, keep oneself from drowning. In Rosalind Gill's taboobusting Breaking the Silence, she collates stories from the working lives of academ-

\footnotetext{
7 The 'REF 2021: Decisions on staff and outputs' document specifies that 'the average number of outputs required per FTE will be $2.5^{\prime}(2017,6)$. This translates into a minimum of one output per individual to a maximum of five outputs,

http://www.ref.ac.uk/media/ref,2021/downloads/REF\%202017 04\%20Decisions.pdf, accessed November 21, 2017.
} 
ics and notes "the palpable anxiety that pulsates through these accounts: anxiety about falling behind, missing something important, going under" (Ibid., 47). There are only so many hours in a day. Will you spend them working on a journal article or answering student emails? Either response suggests the production of guilt. If you choose to work on the article, you are aware you are ignoring students. If you choose the emails, you feel guilty that you're shirking your responsibilities as a researcher. This guilt and anxiety is an intimately familiar, perhaps even normalised, feature of contemporary academic life. But its persistence ought to be denaturalised and understood within the context of increasing workloads and pressures on academics to excel in multiple roles, from 'world-leading' researchers to 'excellent' teachers and 'service providers' to professional administrators performing recruitment and (self)marketing tasks. In other words, today's academics are expected to do much more than they were in previous generations (see Gill 2016, 46). Is it any wonder, then, that anxiety, stress and depression feature so prominently in contemporary accounts of what it is to be an academic?

As professionalised subjects disciplined by neoliberalism, many of us have internalised the competitive ethos and metrics of success articulated by the modern university. This internalisation impacts the choices we make; it guides the priorities we (don't) follow through on. It also impacts our individual and collective strategies for response and resistance to our working conditions. We examine these strategies below.

\section{Making the Resistance: Beyond the Neoliberal University}

While increased precarity and the rise of neoliberal audit culture have had significant impacts on academic lives, we have seen surprisingly little collective action from academic workers to resist and challenge these developments (Willmott 1995; Davis and Bansel 2005; Gill 2016). Reasons cited for the lack of resistance range from the passion for academic work as vocation (Ross 2000, 22), "the seductions of relatively autonomous working lives" (Gill 2016, 53) and the relative privilege of being in a permanent academic position, to not knowing what to resist and how, to simply being exhausted (Gill 2016). At a structural level, neoliberal reforms have diminished spaces for democratic decision-making within the university and thus reduced the ability of academics to shape the university in meaningful ways (Parker and Jary 1995). Divisions between permanent academic staff and contingent workers have further complicated the prospects of taking collective action. Over two decades ago, Hugh Willmott $(1995,1003)$ warned that the expansion of short-term and hourly teaching contracts cushions the deterioration of working conditions for permanent academic staff and thus stalls resistance. Today, his warning reads prophetic.

The neoliberal university has impacted academic selves in ways that serve to ensure compliance. Parker and Jary, for example, suggest that "many academics may begin to construct a fetishism of rankings as a measure of the worth of self and other" (1995, 331). David and Bansel $(2005,55)$ argue that academics have internalised metrics of publications, teaching loads and research funds as measures of success. Their "research suggests that external pressures are immediately translated by academic workers into internal pressures for which one must accept responsibility" (David and Bansel 2005, 51). Similarly, Gill $(2016,52)$ argues that academics are particularly susceptible to act as responsibilised subjects: "Neoliberalism found fertile ground in academics whose predispositions to 'work hard' and 'do well' meshed perfectly with its demands for autonomous, self motivating, responsibilised subjects".

Within the neoliberal narrative of individual achievement and responsibility, struc- 
tural problems are often perceived as personal failures. In such a deeply individualised climate, the struggles to meet externally defined standards and to effectively manage growing workloads tend to lead to self-blame rather than collective action. When something goes wrong - when, say, one receives a hostile peer-review or has a grant application rejected - there is no one to blame but oneself. Accordingly, success and failure "are understood to reflect on the value and worth of the individual, rather than the values of the institutions that make intolerable demands" (Gill 2016, 48). As a consequence, as Willmott stresses, performance monitoring and the erosion of pay and conditions have led to "simmering resentment and individual withdrawal [...] rather than organized resistance" $(1995,1002)$. Drawing analogies to the extensive body of research on cultural workers, Gill $(2016,51)$ highlights that the tendency to frame the pressures and stresses of academic life as individual failures often produce feelings of guilt and shame and thus "is profoundly silencing and isolating".

Upholding potentials for structural critique and collective resistance as alternatives to individual self-blame seems crucial not only for the sake of improving the conditions of academic labour, but also for the prospects of a critical academia. As Mary Heath and Peter Burdan argue, academics "have a unique social responsibility to critically examine social institutions, including the university" $(2013,381)$. Any exploration of resistance within and against the neoliberal university needs to take the above limitations seriously but without overlooking a growing array of ideas, proposals and practices to contest neoliberal academic life and imagine alternatives. Contrary to the above accounts, Gina Anderson $(2008,252)$ argues that "resistance is a likely response to managerialism" within the university since academics are inured to critique rather than acceptance. Resistance can take many shapes and forms. While David and Bansel $(2005,57)$ argue that it requires acts of collegiality, collaboration and collectivity, many of the micro-resistances Anderson (2008) identifies in her research on Australian academics seem to rely on individual resistance rather than collective action. These individual tactics include minimal compliance with managerial demands or refusing to participate in student evaluations, staff surveys, workload interviews and other managerial exercises (Ibid.).

To further explore the various starting points for resistance, we identify four different responses that can be used to express discontent with neoliberal academia: abstention, attack, adaptation and alternatives. This framework is based on a typology Dieter Rucht $(2004,31 \mathrm{f})$ introduced to describe different ways that social movements engage with mass media. Abstention refers to a strategy of withdrawal and retreat: a refusal to engage with mass media. Attack describes "an explicit critique of, and sometimes even violent action against, the mass media" (Rucht 2004, 31). The strategy of adaptation accepts the mass media's rules and tries to exploit them to further the movement's goals. The final strategy describes the attempt to build independent movement media as alternatives to established mass media. In the following, we will apply these four strategies to how academics are dealing with the injuries and challenges of neoliberal academia.

\subsection{Abstention}

For many, abstaining from an academic career is not a choice. The increased prevalence of contingent employment and precarious work in academia often forces early career scholars to look for career paths outside the university. However, even for those with more permanent positions, sometimes the only way to escape the problems of academic labour is withdraw from it. 
There are many reasons to take the conscious decision to abandon the pursuit of an academic career, and the decision to quit academia is not always just a personal one. Often it is an active gesture of resistance against university power structures and working conditions. For example, in 2016, Sara Ahmed resigned from her position as director of the Centre for Feminist Research at Goldsmiths, University of London in protest against the university's response to alleged sexual harassment of students (Ahmed 2016). Liz Morrish left her university job after facing disciplinary procedures for speaking out about the stresses and pressures of academic labour in front of students and in public. Her decision to leave was an attempt, in Morrish's (2017) words, to "reclaim my academic freedom - outside the academy". For Tamura A. Lomax, the decision to quit academia was a form of resistance that allowed her to publicly condemn the racism and sexism black women often face within university environments. She left because "the growing precariat within academe impacts those who are racialized and gendered in the most harmful ways and divides the academic master/servant class even further" (Lomax 2015).

Rather than framing abstention from academic life solely as a matter of personal choice, it is important to acknowledge that who gets in and who doesn't, who quits and who stays, tends to reflect existing inequalities of race, class and gender. Women, for instance, are more likely to leave academia. According to a 2006 study of chemistry PhD students in the UK, only $12 \%$ of women in the third year of their PhD studies wanted to remain in academia, compared to $21 \%$ of their male counterparts (Royal Society of Chemistry 2008). Qualitative follow-up research showed that it was particular "experiences of the structures, cultures, environment and norms of practice" during their PhD studies that deterred women from wanting to pursue an academic career. Among other factors, women pointed out that they "would prefer if academic chemistry was more cooperative in nature" (lbid.).

As a resistance strategy abstention is inward-oriented, i.e. directed towards changing individual behaviour (Rucht 2004, 32). However, taking the difficult personal decision to leave academia behind can itself highlight the need for change and inspire others to act.

\subsection{Attack}

While abstention is directed inward, the strategy of attack is outward-focused (Rucht 2004, 32). Attack can be both individual and collective. Individual attacks against the neoliberal university may include deciding to confront managers or Vice-Chancellors at staff meetings, speaking out to students about managerialism in the university or opting for minimal compliance with managerial demands (Anderson 2008). Collective forms of attack have traditionally been organised through labour unions. In the UK, the University and College Union (UCU) is making important efforts to make visible and improve working conditions in academia, making the fight, for example, against casualisation and the gender pay gap campaigning priorities. However, thus far unions have not been very successful in fending off wage declines, increasing workloads or institutional reliance on temporary (and often part-time) contracts. Gill (2016, 45) suggests that the "idea of scholarship as a 'noble' calling or vocation" might have contributed to the "failure over many decades to secure pay deals that even keep pace with inflation". She also stresses that the educational and cultural capital that comes with the academic profession risks masking financial hardship (Gill 2016, 45). But, as one of our academic friends put it, 'I can't eat cultural capital'.

A recent UK example of the limited success of union activism is the pay deal UCU agreed in May 2014. After six days of strike action and months of campaigning, the 
deal merely reaffirmed a $1 \%$ pay rise that had already been on offer for the academic year 2013-2014 and included a promise for a $2 \%$ rise the following year. ${ }^{8}$ This deal came after real wages had fallen by $13 \%$ since 2008 , and as such, it was criticised as being not a "pay deal" but in fact a "pay cut" (Freedman 2014). However, organised resistance in universities is not only coming from academic staff. A more successful campaign was, for example, started in 2012 by outsourced cleaning staff at the University of London. The 3 Cosas Campaign demanded improvements for contract workers employed by the University, focusing primarily on paid sick leave, paid holidays and pensions. After over a year of strikes and protests the campaign achieved significant improvement in terms of pay, including holiday and sick pay entitlements. ${ }^{9}$

Collective resistance in the form of union activism faces significant challenges within the contemporary context. In universities, the rise in student fees and the redefinition of students as customers has intensified divisions between academics and students and thus threatens the potentials for solidarities between them. Furthermore, considering growing workload demands, strike action is less effective if it means that work is not in fact stopped but merely postponed to the next day, the evening or the weekend. And yet, the union as an institutionalised means for collective mobilisation and solidarity remains a unique tool for resistance and giving up on it would mean a historic defeat.

\subsection{Adaptation}

A third possible response to the stresses of academic life is to develop practical strategies for buffering periods of intense pressures and excessive work demands. This can be an important survival tactic for maintaining sanity and avoiding burnout. However, in the long-run such a strategy contributes little to efforts aimed at contesting and changing the conditions of academic labour. For example, in an article entitled 'How to live less anxiously in academe', Cederström and Marinetti (2016) argue that hopes for sudden resolution to the problems of academic life are futile. Instead, they suggest four strategies for academics "who have grown tired of this futile moaning and wish to do something about it". These strategies include giving up institutional aspirations, embracing the fact that academics are amateur writers and amateur teachers, stopping to write badly and starting to teach well.

On the one hand, this advice to finally start writing and teaching well seems to add to, rather than reduce, the pressure and anxiety of academic life. On the other hand, the suggested strategies offer a deeply individualised outlook. Cederström and Marinetti (2016), for instance, advise "to keep a low profile, and just live up to the basic expectations. Smile and nod, but don't overdo it". Such a strategy only deals with the effects of managerialism and excessive workloads rather than the causes. It does not demand or create systemic change. As Davies and Bansel $(2005,55)$ argue, "drawing boundaries around work might help academics manage their workloads but it has little impact on the systemic causes of their distress". As a consequence of such efforts of "work deflection", workloads are likely to simply be shifted to other members of staff. If some individuals, for example, refuse to take on additional admin or committee work, others will be burdened with these tasks. One's colleagues, in other words, will have to pick up the slack. This further exacerbates workload inequalities between academics, in this case between those who are comfortable saying no to

${ }^{8}$ https://www.ucu.org.uk/hepay13, accessed May 12, 2017.

9 https://3cosascampaign.wordpress.com/about, accessed May 12, 2017. 
taking on additional work tasks and those who are not (or those who cannot - e.g. those on temporary contracts or junior academics on probation). Moreover, this inequality is likely to evolve along gendered lines. Finally, a strategy that only tackles symptoms will ultimately exacerbate frustrations and fuel feelings of inadequacy. As Ryan explains, focusing solely on avoiding symptoms "allows us to survive as zombies rather than escape the plague" $(2012,10)$.

\subsection{Alternatives}

A way to address the tension between passion for academic work and the realities of academic labour is to reclaim higher education and create alternatives to the neoliberal university. The drive to build alternatives is based on a conscious conceptualisation of "the university as a set of practices that are historically contingent and capable of transformation" (Heath and Burdan 2013, 398). Unlike the previous three strategies, alternatives are necessarily collective. Alternatives cannot be built by isolated individuals but require a group of people to work together to create systemic change. Alternatives can be envisioned both within and outside established universities.

Ideas for creating alternatives within established academic institutions focus on actively resisting individualisation and competition, and instead creating work cultures based on care, co-operation and solidarity. As the SIGJ2 Writing Collective (2012, 1055) puts it, this is an attempt to "find ways to be the change we want to see in academia". To that end, the Collective suggests focusing on collective instead of individual publishing, making research outputs freely available online, being generous when assessing each other's work and placing value on activities such as community engagement or activism when evaluating academic CVs. The Collective also proposes strengthening links between scholarship and activism in order to more directly challenge the structures of neoliberal capitalism (The SIGJ2 Writing Collective 2012, 257f). A similar proposal comes from a group of feminist writers who suggest slow scholarship as an "alternatives to the fast-paced metric-oriented neoliberal university" (Mountz et al. 2015, 1236). Starting from a feminist ethics of care they frame slow scholarship as an explicitly collective strategy of resistance where the goal is to cultivate "caring academic cultures and processes" (Mountz et al. 2015, 1238) and reclaim time for collaborative and care-full scholarship.

Unlike strategies of adaptation discussed earlier, the call for slow scholarship does not just explore ways to improve individual resilience and well-being, but seeks to develop alternative cultures within the university through collective action. The group highlights that "slow scholarship cannot just be about making individual lives better, but must also be about re-making the university" (Ibid.). They propose a set of strategies and actions that can be taken collectively to shift individualised, competitive, fast-paced and metrics-oriented academic cultures. These include supporting colleagues and students to develop slow strategies, counting as legitimate and valuable a wider range of work such as collaboration and advocacy when discussing promotion, tenure or hiring, organising spaces for collaboration and sharing of ideas such as reading and writing groups, coffee breaks or joint conference panels, taking care of and supporting colleagues, writing fewer emails, turning off email at evenings and weekends, prioritising time to think, making time for careful writing, sharing strategies of saying no when overburdened with work as well as saying yes to opportunities to support slow scholarship, reaching for the minimum and being satisfied with good enough. Similarly, the Res-Sisters, a feminist collective of early career academics, stress that collectivity is needed in order to resist neoliberal individualisation, "providing support networks and helping us to organise against institutional and societal in- 
justices" (2016)..$^{10}$

These suggestions focus on reclaiming agency for academic workers and challenging feelings of powerlessness. They highlight that, despite incentives to do so, academics do not need to act in competitive ways but can instead join together and behave differently to actively re-imagine academic work cultures in a way that prioritises care, critical thinking and activism over metrics like citation counts and publication numbers.

While the above proposals focus on transforming universities from within, others highlight the need for building a completely new model of the university. Some attempts to create organisational alternatives focus on proposals to build a cooperative university (Ridley-Duff 2011; Cook 2013; Neary and Winn 2016; Winn 2015). This model offers a vision of a university that is owned and controlled by its workers, including not only academics but also support staff and students. Ideas for creating a co-operative university range from converting existing universities into cooperatives to creating co-operatives at the level of department, research group and curriculum to setting up new co-operative universities (Winn 2015, 41).

A well-established example of a co-operative university is Mondragon University in Spain, which is part of the Mondragon Federation of Co-operatives. It, however, has been criticised for its overly functional approach and goal of directly benefitting the business activities of the Mondragon Corporation (Kasmir 1996; Winn 2015, 44). In the UK, the Social Science Centre in Lincoln, which is organised as a not-for-profit co-operative, is actively trying to develop alternative structures of higher education. ${ }^{11}$

The co-operative university suggests a complete reconceptualisation of academic labour and re-imagines the role of higher education in society (Winn 2015, 51; Neary and Hagyard 2010). This model challenges established divisions of labour, power inequalities and hierarchies within the university. Joss Winn $(2015,47)$ explains:

In a worker co-operative university as conceived here, there is a singular role of 'scholar', but a greater diversity of work and significantly less division of labour. According to the individual's capacity, the teacher is also a student, an administrator, a cleaner, etc., and a co-operative university need not do everything that a conventional university aims to do.

In addition to placing control and decision-making power in the hands of university workers the co-operative university furthermore proposes to radically alter the relationship between students and teachers. It conceptualises the student not as a consumer but a producer of knowledge (Neary and Winn 2016) and an "active contributor" (Winn 2015, 50). This reconfigured relation between students and teachers also calls into question the purpose of higher education (Neary and Hagyard 2010), which, as Winn suggests, "is not the production of students for wage labour, but rather the production of knowledge appropriate to the needs of humanity" (Winn 2015, 49; see also Brown 2015). Proposing co-operative alternatives to established univer-

10 The Res-Sister Manifesta, 2016, https://ressisters.wordpress.com/manifesta, accessed November 15, 2017.

${ }^{11}$ The Social Science Centre, Lincoln, http://socialsciencecentre.org.uk, accessed November 15, 2017. 
sities is thus an opportunity not just to rethink the conditions of academic labour but also the societal role of higher education. As Perez Ruiz (2015) argues, "a cooperative education would be an emancipatory education, focused in developing agency among workers (students or otherwise)".

The attempts discussed here to create alternatives to the neoliberal university whether from inside or outside established institutions - are not mutually exclusive but complement each other. Together they offer a set of starting points for envisioning higher education differently and for building a university in accordance with a different set of structures, values and practices than those imposed by today's neoliberal context.

\section{Conclusion}

This article has been concerned with the state of higher education in the UK. We have argued that the experience of the individual academic needs to be understood in the wider context of neoliberal capitalism, its institutions and its imperatives. This context is shaped by, and supports, the hegemony of metric power in today's universities - a hegemony that actively transforms knowledge from a public good to a private resource (Brown 2015).

In examining responses that resist, challenge or in some cases, compound, the problems identified, we see that responses by dissatisfied academics range in style and approach to the mantras of neoliberalism. Some decide against an academic career; others adopt a strategy of individual withdrawal within the system by trying to create and protect spaces of independence. These responses are not without problems: some offer immediate but limited relief from the pressures of academic life, while others suggest radical alternatives that require systemic change. Despite their relative (dis)advantages, all of these responses offer much-needed alternatives to self-blame, individualisation and competition.

Contra the prevailing tide of individualisation, we suggest that opportunities for positive systemic change can be found in collective efforts to disrupt the status quo and to create alternatives for how academic labour is organised. Therein, solidarity can act as an instrument of opposition to the privatisation of both knowledge and the neoliberal academic self. Considering such a strategy involves discussing the viability of union activism within the British university as well as exploring the prospect of a politics of the everyday that resists interpellation by the myth of meritocracy (Littler 2018).

Neoliberal academia frames achievement as purely personal 'accomplishments' (or failures). But as we have suggested, the individualisation of results needs to be approached as part of a much wider system of (re)production. That system has rendered the university little more than a series of numeric measures, benchmarks and accounting exercises. It is therefore urgent that we work together, through networks of solidarity, to rehabilitate the university as an institution of and for public knowledge. This cannot happen in isolation - as we have argued in this paper, the university as we know it is embedded within and shaped by the structures of capitalism in general and neoliberalism in particular. Any effort to create a different university must be part of broader alliances and movements for social change.

\section{References}

Ahmed, Sara. 2016. Resignation is a Feminist Issue. feministkilljoys. Accessed May 5, 2017. https://feministkilljoys.com/2016/08/27/resignation-is-a-feminist-issue 
Ajana, Btihaj. 2017. Metric Culture: The Quantified Self and Beyond Conference. Accessed January 12, 2017. http://metriclife.net/whats-on/international-conference -metric-culturethe-quantified-self-and-beyond

Anderson, Gina. 2008. Mapping Academic Resistance in the Managerial University. Organization 15 (2): 251-270.

Bauman, Zygmunt. 2001. The Individualized Society. Cambridge: Polity Press.

Beck, Ulrich and Elisabeth Beck-Gernsheim. 2002. Individualization: Institutionalized Individualism and Its Social and Political Consequences. London: Sage.

Beer, David. 2016. Metric Power. London: Palgrave Macmillan.

Braverman, Harry. 1998. Labour and Monopoly Capitalism: The Degradation of Work in the Twentieth Century. New York: Monthly Review Press.

Brown, Wendy. 2015. Undoing the Demos: Neoliberalism's Stealth Revolution. New York: Zone Books.

Bulut, Ergin. 2011. Creative Economy: Seeds of Social Collaboration or Capital's Hunt for General Intellect and Imagination? In Cognitive Capitalism, Education and Digital Labour, edited by Michael A. Peters and Ergin Bulut, 151-168. New York: Peter Lang.

Cederström, Carl and Michael Marinetti. 2016. How to Live Less Anxiously in Academe. The Chronicle of Higher Education. Accessed May 13, 2017. http://www.chronicle.com/article/How-to-Live-Less-Anxiously-in/237920

Convention for Higher Education. 2016. In Defence of Public Higher Education: Knowledge for a Successful Society: The Alternative White Paper for Higher Education. Convention for Higher Education. Accessed November 14, 2017. https://heconvention2.files.wordpress.com/2016/06/awp1.pdf

Cook, Dan. 2013. Realising the Co-operative University. A Consultancy Report for the Cooperative College. Accessed April 25, 2017. http://josswinn.org/wpcontent/uploads/2013/12/realising-the-co-operative-university-for-disemmination.pdf

Davies, William. 2014. The Limits of Neoliberalism. London: Sage.

Davies, Bronwyn and Peter Bansel. 2005. The Time of Their Lives? Academic Workers in Neoliberal Time(s). Health Sociology Review 14 (1): 47-58.

De Angelis, Massimo and David Harvie. 2009. 'Cognitive Capitalism' and the Rat-Race: How Capital Measures Immaterial Labour in British Universities. Historical Materialism 17 (3): 3-30.

Department for Business, Innovation \& Skills. 2016. Success as a Knowledge Economy: Teaching Excellence, Social Mobility and Student Choice: Government White Paper. Accessed May 5, 2017.

https://www.gov.uk/government/uploads/system/uploads/attachment data/file/523396/bis16-265-success-as-a-knowledge-economy.pdf

Dyer-Witheford, Nick. 2011. In the Ruined Laboratory of Futuristic Accumulation: Immaterial Labour and the University Crisis. In Cognitive Capitalism, Education and Digital Labour, edited by Michael A. Peters and Ergin Bulut, 275-286. New York: Peter Lang.

Evans, Mary. 2005. Killing Thinking: The Death of the Universities. London: Continuum.

Foucault, Michel. 2007. Security, Territory, Population: Lectures at the Collège de France 1977-1978. Basingstoke: Palgrave Macmillan.

Freedman, Des. 2014. Universities in Dispute: Pay Deal is a Pay Cut. Counterfire. Accessed April 12, 2017. http://www.counterfire.org/articles/analysis/17180-universities-in-disputepay-deal-is-a-pay-cut

Gaze, Beth and Carolyn Stevens. 2011. Running Risks of Gender Inequity: Knowledge Transfer Policy in Australian Higher Education. Journal of Education Policy 26 (5): 621639.

Gill, Rosalind. 2016. Breaking the Silence: The Hidden Injuries of Neo-Liberal Academia. Feministische Studien 34 (1): 39-55.

Gill, Rosalind. 2014. Academics, Cultural Workers and Critical Labour Studies. Journal of Cultural Economy 7 (1): 12-30. 
Giroux, Henry A. 2011. Neoliberalism and the Death of the Social State: Remembering Walter Benjamin's Angel of History. Social Identities 17 (4): 587-601.

Gornall, Lynne and Jane Salisbury. 2012. Compulsive Working, 'Hyperprofessionality' and the Unseen Pleasures of Academic Work. Higher Education Quarterly 66 (2): 135-154.

Gruber, Thorsten. 2014. Academic Sell-Out: How an Obsession with Metrics and Rankings is Damaging Academia. Journal of Marketing for Higher Education 24 (2): 165177.

Heath, Mary and Peter D. Burdon. 2013. Academic Resistance to the Neoliberal University. Legal Education Review 23 (2): 379-401.

HESA. 2017. Income and Expenditure of Higher Education Providers in 2015/2016. Accessed May 22, 2017. https://www.hesa.ac.uk/news/02-03-2017/income-and-expenditure. A detailed accounting can be accessed at: https://www.hesa.ac.uk/files/prerelease/heuk finances 1516 all tables.xlsx (especially Table 16 and Table 17).

Hicks, Diana, Paul Wouters, Ludo Waltman, Sarah de Rijcke and Ismael Rafols. 2015. The Leiden Manifesto for Research Metrics. Nature 520: 429-431.

Jump, Paul. 2013. Evolution of the REF. Times Higher Education. Accessed May 3, 2017. https://www.timeshighereducation.com/features/evolution-of-the-ref/2008100.article

Kasmir, Sharryn. 1996. The Myth of Mondragon: Cooperatives, Politics and Working-Class Life in a Basque Town. Albany: State University of New York Press.

Littler, Jo. 2018. Against Meritocracy: Culture, Power and Myths of Mobility. Oxon: Routledge.

Lomax, Tamura A. 2015. Black Women's Lives Don't Matter in Academia Either, or Why I Quit Academic Spaces That Don't Value Black Women's Life and Labor. The Feminist Wire. Accessed May 10, 2017. http://www.thefeministwire.com/2015/05/black-womenslives-dont-matter-in-academia-either-or-why-i-quit-academic-spaces-that-dont-valueblack-womens-life

Lupton, Deborah. 2016. The Quantified Self. Cambridge: Polity.

McPhail, Will. 2017. These Smug Pilots Have Lost Touch with Regular Passengers Like Us. Who thinks I should fly the plane? New Yorker. Accessed December 15, 2017. https://www.newyorker.com/cartoon/a20630

Moore, Phoebe and Andrew Robinson. 2015. The Quantified Self: What Counts in the Neoliberal Workplace. New Media \& Society 18 (1): 2774-2792.

Morrish, Liz. 2017. Why the Audit Culture Made Me Quit. Times Higher Education. Accessed April 29, 2017. https://www.timeshighereducation.com/features/why-audit-culture-mademe-quit\#survey-answer

Mountz, Allison, Anne Bonds, Becky Mansfield, Jenna Loyd, Jennifer Hyndman, Margaret Walton-Roberts, Ranu Basu, Rita Whitson, Roberta Hawkins, Trina Hamilton and Winifred Curran. 2015. For Slow Scholarship: A Feminist Politics of Resistance Through Collective Action in the Neoliberal University. ACME: An International E-Journal for Critical Geographies 14 (4): 1235-1259.

Neary, Mike and Andy Hagyard. 2010. Pedagogy of Excess: An Alternative Political Economy of Student Life. In The Marketisation of Higher Education and the Student as Consumer, edited by Mike Molesworth, Richard Scullion and Elizabeth Nixon, 209-223. London: Routledge.

Neary, Mike and Joss Winn. 2016. Beyond Public and Private: A Framework for Co-operative Higher Education. Conference Paper Presented at the Co-operative Education Conference 2016. Accessed April 29, 2017. http://eprints.lincoln.ac.uk/23051/1/CoopHEconferencepaper2016.pdf

Neeman, Yael. 2016. We Were the Future. New York: Overlook Duckworth.

Nichols, Tom. 2017. The Death of Expertise: The Campaign Against Established Knowledge and Why It Matters. New York: Oxford University Press.

Noble, David. 1997. The Religion of Technology: The Divinity of Man and the Spirit of Invention. New York: Knopf. 
Parker, Martin and David Jary. 1995. The McUniversity: Organization, Management and Academic Subjectivity 2 (2): 319-338.

Pells, Rachael. 2017. Students 'Boycotting' NUS National Student Survey Boycott, Independent. Accessed March 30, 2017. http://www.independent.co.uk/student/news/students-boycotting-nus-national-studentsurvey-oxford-university-warwickcambridge-tef-tuition-fees-a7598216.html

Perez Ruiz, Pablo. 2015. What is University For? The Columnist. Accessed May 3, 2017. http://www.columnistmagazine.co.uk/post/130265331865/what-is-university-for

Peters, Michael A. and Ergin Bulut, eds. 2011. Cognitive Capitalism, Education and Digital Labour. New York: Peter Lang.

Power, Michael. 1994. The Audit Explosion. London: Demos.

Ridley-Duff, Rory. 2011. Co-operative University and Business School: Developing an Institutional and Educational Offer. UK Society for Co-operative Studies. Accessed December 15, 2017: http://josswinn.org/wp-content/uploads/2013/11/Co-operative-UniversityInstitutional-and-Educational-Offer-Draft-3.pdf

Roggero, Gigi. 2011. The Production of Living Knowledge: The Crisis of the University and the Transformation of Labor in Europe and North America. Philadelphia: Temple University Press.

Ross, Andrew. 2000. The Mental Labour Problem. Social Text 18 (2): 1-31.

Royal Society of Chemistry. 2008. The Chemistry PhD: The Impact on Women's Retention. London. Accessed December 15, 2017.

https://www.wisecampaign.org.uk/uploads/wise/files/archive/the chemistry phdwomensre tention tcm18-139215.pdf

Rucht, Dieter. 2004. The Quadruple 'A': Media Strategies of Protest Movements Since the 1960s. In Cyberprotest: New Media, Citizens and Social Movements, edited by Wim van de Donk, Brian D. Loader, Paul G. Nixon and Dieter Rucht, 25-48. London: Routledge.

Ryan, Suzanne. 2012. Academic Zombies. A Failure of Resistance or a Means of Survival? Australian Universities Review 54 (2): 3-11.

Shore, Cris. 2008. Audit Culture and Illiberal Governance: Universities and the Culture of Accountability. Anthropological Theory 8 (3): 278-298.

SIGJ2 Writing Collective. 2012. What Can We Do? The Challenge of Being New Academics in Neoliberal Universities. Antipode 44 (4): 1055-1058.

Skelton, Christine. 2005. The 'Self-Interested' Woman Academic: A Consideration of Beck's Model of the 'Individualised Individual'. British Journal of Sociology of Education 26 (1): 516.

Stelmach, Bonnie L. and Stuart D. Von Wolff. 2011. A Challenge to Metrics as Evidence of Scholarity. European Educational Research Journal 10 (1): 64-82.

The Res-Sisters. 2016. 'I'm an Early Career Feminist Academic: Get Me Out of Here?' Encountering and Resisting the Neoliberal Academy. In Being an Early Career Feminist Academic: Global Perspectives, Experiences, and Challenges, edited by Rachel Thwaites and Amy Pressland, 267-284. London: Palgrave.

Thornton, Margaret. 2013. The Mirage of Merit. Australian Feminist Studies 28 (76): 127-143.

Toscano, Alberto. 2011. The Limits of Autonomy: Cognitive Capitalism and University Struggles. In Cognitive Capitalism, Education and Digital Labour, edited by Michael A. Peters and Ergin Bulut, 259-274. New York: Peter Lang.

Wigger, Angela and Hubert Buch-Hansen. 2013. Competition, the Global Crisis, and Alternatives to Neoliberal Capitalism: A Critical Engagement with Anarchism. New Political Science 35 (4): 604-626.

Willmott, Hugh. 1995. Managing the Academics. Commodification and Control in the Development of University Education in the UK. Human Relations 48 (9): 993-1027.

Wilsdon, James, Liz Allen, Eleonora Belfiore, Philip Campbell, Stephen Curry, Steven Hill, Richard Jones, Roger Kain, Simon Kerridge, Mike Thelwall, Jane Tinkler, lan Viney, Paul Wouters, Jude Hill and Ben Johnson. 2015. The Metric Tide: Report of the Independent 
Review of the Role of Metrics in Research Assessment and Management. HEFCE. Accessed December 15, 2017. http://www.hefce.ac.uk/media/HEFCE,2014/Content/Pubs/Independentresearch/2015/The ,Metric,Tide/2015 metric tide.pdf

Winn, Joss. 2015. The Co-operative University: Labour, Property and Pedagogy. Power \& Education 7 (1): 29-55.

\section{About the Authors}

Zeena Feldman

Zeena Feldman is Lecturer in Digital Culture in the Department of Digital Humanities, King's College London.

Marisol Sandoval

Marisol Sandoval is Senior Lecturer at the Centre for Culture and Creative Industries, Department of Sociology, City, University of London. 